VOX PATRUM 77 (2021) 97-112

DOI: $10.31743 / \mathrm{vp} .9703$

Jarosław Dudek ${ }^{1}$

\title{
Metropolici Dyrrachion wobec naturalnych katastrof i kryzysu Bizancjum w XIII wieku²
}

Następstwa czwartej krucjaty stanowią ważną cezurę w historii metropolii dyrracheńskiej³. Miejscowy Kościół przetrwał różne barbarzyń-

1 Dr hab. Jarosław Dudek, profesor Uniwersytetu Zielonogórskiego w Instytucie Historii Polskiej; e-mail: j.dudek@ih.uz.zgora.pl; ORCID: 0000-0002-2895-2586.

2 Niniejszy tekst był wygłoszony jako referat na V Ogólnopolskiej Konferencji Bizantynistycznej z cyklu Wybrane aspekty kultury bizantyńskiej: „Bizantyńskie doktryny z zakresu filozofii władzy, teologii politycznej oraz ideologii wojny”, Lublin, 21-22 listopada 2019 roku.

3 Położone na zachodnich obrzeżach Bałkanów Dyrrachion (obecnie albańskie Dürres) posiadało długą i złożoną tradycję więzi z państwem bizantyńskim. Miasto we wczesnych wiekach średnich stopniowo urosło do rangi głównego ośrodka administracji bizantyńskiej w zachodniej części Półwyspu Bałkańskiego. Wiązało się to z jego rolą w kontaktach Bizancjum z Serbami, Bułgarami, Normanami oraz szlakiem krucjat w XI-XII wieku. Zob. T.E. G(regory), Dyrrachion, w: The Oxford Dictionary of Byzantium, t. 2, red. A. Kazhdan et al., New York - Oxford 1991, s. 668 (dalej cyt. ODB); S. Rek, Dracz, w: Słownik starożytności słowiańskich, t. 8, cz. 1: Suplementy i indeksy, Wrocław - Warszawa 1991, s. 67-69; J. Dudek, ,Cała ziemia dyrracheńska” pod panowaniem bizantyńskim w latach 1005-1205, Zielona Góra 1999. Świadectwa archeologiczne potwierdzają utrzymanie w VII-VIII wieku przez Dyrrachion roli lokalnego centrum pobudzającego aktywność kulturową szeregu postrzymskich społeczności wzdłuż zachodniego odcinka drogi Via Egnatia, od nadmorskich enklaw po wielkie jeziora górskie (Ochrydzkie i Prespańskie). Zob. E. Nallbani, Transformations et continuité dans l'ouest des Balkans: le cas de la civilisation de Komani (VI-IX siècles), $\mathrm{w}$ : L'Illyrie méridionale et l'Epire dans l'Antiquité. IV. Actes du IV colloque internationale de Grenoble, 10-12 octobre 2002, red. P. Cabannes - J.-L. Lamboley, Paris 2004, s. 481-490; H. Saradi, Aspects of early Byzantine urbanism in Albania, w: The Medieval Albanians, Athens 1998, s. 121-124; E. Kislinger, Dyrrhachion und die Küsten von Epirus und Dalmatien im frühen Mittelalter - Beobachtungen zur Entwicklung der byzantinischen Oberhoheit, „Millenium” 8 (2011) s. 313-352; L.F. Miraj, Dyrrachion in the Early Christian and Byzantine Period, Tiranë 2013. 
skie migracje od czasów wielkiej wędrówki ludów, utrzymując między VII a IX wiekiem rangę ważnej chrześcijańskiej enklawy na zachodnich obrzeżach Półwyspu Bałkańskiego, coraz ściślej zintegrowanych z Konstantynopolem ${ }^{4}$. Teraz jego zwierzchnicy stanęli wobec wyzwań, z którymi zetknęło się wiele pogranicznych prawosławnych społeczności i instytucji. Usytuowanie Dyrrachion na styku prawosławia i katolicyzmu, $\mathrm{w}$ powiązaniu $\mathrm{z}$ niepewnym statusem metropolii $\mathrm{w}$ nowych czasach wszystko to uwidoczni się w obliczu spowodowanej siłami natury katastrofy, jaka dotknęła miasto na początku ósmej dekady XIII wieku. Stan źródeł pozwala na przedstawienie skutków tego ostatniego wydarzenia w kontekście polityki papiestwa i jego sojuszników wobec wyznawców prawosławia na zachodnich Bałkanach, przypomni także niewygasłe jeszcze echa rywalizacji o prymat między ośrodkami w Nikei i Epiru.

Podstawową wiedzę o przebiegu trzęsienia ziemi i tsunami w Dyrrachion oraz konsekwencjach zawdzięczamy Jerzemu Pachymeresowi (ok. 1242-1310). Opis wydarzenia, które umieścił na kartach swoich „Dziejów współczesnych", powstał parędziesiąt lat później, co być może przyczyni-

4 F. Dölger, Regesten der Kaiserurkunden des oströmischen Reiches von 565-1453, T. 1: Regesten von 565-1025, München - Berlin 1924, nr 301; Notitiae episcopatuum Ecclesiae Constantinopolitane, texte critique, introduction et notes J. Darrouzès, Paris 1981, s. 216, 222, 231, 236, 265, 272, 274, 286, 292, 305, 330. Zob. R. Janin, Dyrrachium, DHGE XIV 1248-1252; D.J. Pallas, Epirus, w: Encyclopedia of the Early Church, t. 1, red. A. Di Bernardino, Cambridge 1992; V. Grumel, L'annexion de l'Illyricum Oriental, de la Sicile et de la Kalabrie au Patriarchat de Constantinople, RSR 39-40 (1952) s. 191-200; S. Turlej, Konflikt ikonoklastyczny a problem jurysdykcji nad Illyricum, „ZNUJ Studia Religiologica” 29 (1996) s. 33-77; G. Fedalto, Problemi di cronotassi e di giurisdzione nei vescovadi del Ducato di Durazzo fino alla dominazione occidentale, w: Studi Albanologici, Balcani, Bizantini e Orientali in sonore di Giuseppe Valentini, red. L.S. Olschke, Firenze 1986, s. 51-64; J. Dudek, Biskupi Dyrrachion w strukturach patriarchatu Konstantynopola (VII-X w.), VoxP 58 (2013) s. 221-236; Odnośnie do sfery kultury materialnej, zob. Saradi, Aspects of early Byzantine urbanism in Albania, s. 85-89, 98-101, 104. W późniejszych wiekach, zwłaszcza pod rządami cesarzy Jana I Tzymiskesa (969-976) oraz Bazylego II (976-1025) granice oraz instytucje metropolii zostały ustabilizowane. W XI-XII wieku tutejsi biskupi, ustępując wprawdzie randze i znaczeniu swoim ochrydzkim czy tesalonickim sąsiadom, zaliczali się do grona ważnych hierarchów w tej części Bałkanów. Nierzadko wywodzili się spośród stołecznego kleru, uczestnicząc w zebraniach synodów lub sądów, wpływając na ich teologiczne lub prawne rozstrzygnięcia. Zob. Les regestes des actes du patriarchat de Constantinople, vol. Les actes des patriarches, fasc. III. Les regestes de 1043 a 1206, ed. V. Grumel, Paris 1947, nr 921, 1015, 1038, 1077; J. Dudek, Metropolici Dyrrachion od VII do XIII wieku. Próba charakterystyki, „Balcanica Posnaniensia. Acta et studia” 18 (2011) s. 71-73. 
ło się do jego mylnej datacji na marzec 1273 roku. Katastrofa rzeczywiście nastąpiła w marcu, ale doszło do niej prawdopodobnie dwa lata wcześniej w 1271 roku, ewentualnie w 1270 roku$^{5}$. Historyk w miarę szczegółowo przedstawił kataklizm, jaki spadł na dyrracheńczyków bez względu na religię i status. Silne trzęsienie ziemi doprowadziło do prawie całkowitego zniszczenia miasta. Pierwszym objawem zbliżającego się kataklizmu miał być słyszalny z daleka huk, niczym grom dobiegający nie z niebios a spod ziemi. Potem z niespotykaną mocą zatrzęsła się ziemia, zniszczone zostały prawie wszystkie budynki w mieście. Z opisu Pachymeresa wynika, że do kataklizmu doszło prawdopodobnie w nocy, co przyczyniło się do ogromnej liczby ofiar. Przerażeni mieszkańcy wybiegli z rozpadających się domów na ulice, gdzie ginęli pod gruzami. Trzęsieniu ziemi towarzyszyło tsunami, które zatopiło przynajmniej część miasta. Ocalała tylko cytadela, której potężne mury oparły się wstrząsom. Rankiem dyrracheńczycy chwycili za dostępne im narzędzia, przystępując do ratowania zasypanych. W zniszczonym mieście jednak zapanował szybko chaos, stąd ich spontaniczne działania przerodziły się w rabunki, gwałty i morderstwa. Po kilku dniach chaosu ocaleni wespół z okolicznymi Albańczykami zrujnowali największe miasto zachodniego pogranicza Bizancjum. W praktyce oznaczało to destrukcję tutejszej wspólnoty. Pachymeres surowo ocenia dyrracheńskiego metropolitę Niketasa za przyczynienie się do duchowego upadku wiernych powierzonych jego opiece. Porzucił on bowiem swoją katedrę, zabierając naczynia liturgiczne i relikwie, uniemożliwiając w ten sposób odprawianie obrzędów w świątyniach miasta $^{6}$. Dalej Pachymeres konstatuje, że zrujnowanym i wyludnionym mia-

Georgius Pachymeres, Relationes historicas V 7, ed. A. Failler - V. Laurent, Paris 1984, s. 457. Zob. D. Nicol, The Despotate of Epiros 1267-1479 A contribution to the history of Greece in the middle ages, Cambridge 1984, s. 15. Por. A. Failler, Chronologie et composition dans l'Histoire de Georges Pachymère (cz. II), REB 39 (1981) s. 214-218; H.-M. Congourdeau, Les Byzantines face aux catastrophes naturelles sous les Paléologues, REB 67 (2009) s. 152; E. Guidoboni - A. Comastri, Catalogue of earthquakes and tsunamis in the Mediterranean area from the $11^{\text {th }}$ to the $15^{\text {th }}$ Century, Rome 2005, s. 279-283. W dziejach Dyrrachion było to już trzecim, znanym nam, dotykającym miasto kataklizmem, pierwszy nastąpił w 346 roku, drugi zaś - w 522 roku. Materialne następstwa opisanego przez Pachymeresa trzęsienia ziemi miały być zauważalne w mieście przez pielgrzymującego do Ziemi Świętej franciszkanina Simona Fitzsmonsa jeszcze w 1322 roku. Zob. S. Santoro, Lo stato degli studi sull'urbanistica di Epidamnos-Dyrrachium, w: Progetto Durrës. L'idagine sui beni culturali albanesi dell' antichità e del Medioevo. Tradizioni di studio a confronto, red. M. Buora - S. Santoro, Trieste 2003, s. 155, 184, 191-193.

6 Georgius Pachymeres, Relationes historicas V 7, ed. A. Failler - V. Laurent, Paris 1984, s. 457-459. 
stem niebawem, bo w 1273 roku zawładnął kolejny wróg Romajów - Karol I Andegawen (1265-1285). Jako zdobywca południowowłoskiego królestwa Hohenstaufów oraz spadkobierca ostatniego cesarza łacińskiego planował zawładnąć Konstantynopolem ${ }^{7}$. W relacji historyka brak informacji o cesarskich namiestnikach w Dyrrachion w poprzednich wiekach zarządzających obszerną częścią zachodnich Bałkanów. Aż do katastrofy miasto kontrolował cesarz Michał VIII Paleolog (1261-1282), władzę nad nim zawdzięczając swoim nikejskim poprzednikom. Jeden z nich, Teodor II Laskarys (1254-1258) opanował Dyrrachion wraz z innymi kluczowymi ośrodkami tej części zachodnich Bałkanów w 1256 roku. Cesarzy formalnie reprezentował w mieście dygnitarz $\mathrm{w}$ randze duksa lub stratega. Nie wiadomo, czy któryś z nich był wówczas w mieście i z jakich względów Pachymeres skupił się w swoim opisie wydarzeń na zachowaniu biskupa Niketasa.

Katastrofa, jaka dotknęła Dyrrachion, nie uszła uwadze innych autorów z szeroko pojmowanego bizantyńskiego kręgu kulturowego. Miasto, znane Bułgarom i Serbom jako Dracz (Арац), zostało opisane w jednym z ówczesnych apokaliptycznych tekstów jako grzeszne i dręczone przez żmije (smoki), których ogień strawi je na popiół, wywołując nędzę i głód pośród jego mieszkańców ${ }^{8}$. Konkretniejsze odniesienia do tragedii dostarcza już świadectwo sporządzone na peryferiach prawosławnej ekumeny. Jest nim „Słowo o niedowiarstwie” biskupa włodzimiersko-suzdalskiego św. Serapiona (zm. 1275). W powstałej krótko przed śmiercią homilii kreśli on sugestywny obraz katastrofy, jaka spotkała mieszkańców Dracza.

7 Georgius Pachymeres, Relationes historicas V 7, ed. A. Failler - V. Laurent, s. 459. Tym bardziej że towarzyszy temu osadzenie łacińskiego hierarchy w Dyrrachion. Zob. Nicol, The Despotate of Epiros 1267-1479, s. 15. Zajęcie miasta i okolic poprzedziło utworzenie nowego tworu politycznego, który miał się stać kolejnym królestwem Andegawenów oraz przyczółkiem wpływów na Bałkanach - „Regnum Albaniae”, którego stolicą było Dyrrachion (Durazzo). Zob. H. Buschhausen, Die Marienkirchen von Apollonia in Albanien. Byzantiner, Normannen und Serben im Kampf um die Via Egnatia, Wien 1976, s. 156-159; A. Ducéllier, La façade maritime de l'Albanie au Moyen Age. Durazzo et Valona du XIe au XVe siècle, Thessaloniki 1981, s. 166-177; J. Hauziński J. Leśny, Historia Albanii, Wrocław 1992, s. 73-76.

8 V. Tăpkova-Zaimova - A. Miltenova, Istoriko-apokalptičnata knižnina văv Vizantija i srednovekovna Bălgarija, Sofija 1996, s. 246-247. Jeśli uwzględnić informację (s. 241-242), że tekst jest przeważnie datowany na pierwszą połowę XIII stulecia, to interpretacja sugerująca związek fragmentu dotyczącego Dracza (Dyrrachion) z trzęsieniem ziemi może przemawiać za jego późniejszą datacją. Tym bardziej, że żmij (smok) to fantastyczne zwierzę łączone ze sferą chtoniczną. Zob. D. Forstner, Świat symboliki chrześcijańskiej, tł. W. Zakrzewska - P. Pachciarek - R. Turzyński, Warszawa 1990, s. 304-308. 
Serapion rozpoczyna od potępienia niedowiarstwa (malovje'rje) mieszkańców Włodzimierza i Suzdala. Traktuje je jako ciężki grzech, wymieniając kary Boże, jakie dotknęły tych, którzy go popełnili. Ostrzegając przed nim, sięga po arsenał znanych mu porównań z mitologii czy historii biblijnej. Posłużył się również losem Dracza, zalanego falami morza cztery lata wcześniej czyli w 1271 roku (lub w 1270), wyjaśnia, dlaczego tamtejszych wiernych dotknął tak tragiczny los. Święty Serapion widzi to jako karę Boża spadającą na chrześcijan, którzy postępują gorzej niż poganie. Ci przynajmniej nie zabijają swoich współwyznawców, nie ograbiają ich i nie okłamują. W wypadku chrześcijan zaś niedopuszczalne jest postępowanie zarówno świeckich oraz kleru, który nie potrafi ustrzec powierzonej sobie społeczności przed występkiem ${ }^{9}$.

Z obydwu źródeł wyłania się obraz tragedii, które dotknęły mieszkańców Dracza. Najpierw trzęsienie ziemie, potem następuje równie niszczycielska fala tsunami. Nadejście tej ostatniej musiało wywrzeć szczególne wrażenie wśród współczesnych, skoro szybko zostało skomentowane przez staroruskiego teologa ${ }^{10}$. Obydwu autorów kataklizm zaintrygował, obydwaj posłużyli się jego opisem z myślą o konkretnym jego wykorzystaniu w swoich narracjach. Dla św. Serapiona Dracz to miasto położone na peryferiach ortodoksji. Jego mieszkańców połączył wspólny los z innymi społecznościami grzeszników. Okazali się nimi mieszkańcy Przemyśla, grodu położonego na południowo-zachodnim pograniczu Rusi z łacińską Polską. Podobnie jak dyrracheńczyków przemyślan również dotyka kataklizm przypominający falę tsunami, wskutek deszczów i powodzi miało ich w tym samym czasie utonąć aż dwustu ${ }^{11}$. W „Słowie o niedowiarstwie”

9 Slovo blažennogo Serapiona o malover'je, w: ,, Slova” Serapiona Vladimirskogo, ed. i tł. V.V. Kolesov, Pamjatniki Literatury Drevnej Rusi: XIII vek, Moskva 1981, s. 454-455. Wcześniej jako archimandryta ze sławnej Ławry Pieczerskiej był związany z Kijowem. Zob. G. Podskalsky, Chrześcijaństwo i literatura liturgiczna na Rusi Kijowskiej (988-1237), tł. J. Zychowicz, Kraków 2000, s. 86, 151-155, 385.

10 Równie szybko zostało zastrzeżone i odnotowane w latopisie nowogrodzkim zdobycie Konstantynopola i splądrowanie jego świątyń przez krzyżowców. Wydarzenia te zostały zresztą utrwalone w późniejszym latopisarstwie staroruskim. Zob. Z.A. Brzozowska - I.N. Petrov, Latopis nowogrodzki pierwszy starszej redakcji. Unikatowy zabytek piśmiennictwa staroruskiego i jego polski przekład, Łódź 2019, AM 6712 (AD 1203/1204), s. 82-91; Z.A. Brzozowska, Opowieść o zdobyciu Konstantynopola przez uczestników czwartej wyprawy krzyżowej (6712/1204) w średniowiecznej ruskiej tradycji historiograficznej, ,Slavia Antiqua” 67 (2016) s. 109-151.

11 Slovo blažennogo Serapiona o malover'je, s. 454-455. W jeszcze większym stopniu według Serapiona kataklizm miał dotknąć sąsiednich „Lachów”, których w tym samym czasie utonąć miało aż 600 . 
nie pojawia się żadna wzmianka o politycznych i kościelnych kontaktach z Kościołem rzymskim władcy księstwa halicko-wołyńskiego Daniela Romanowicza (1228-1264). Kilkanaście lat wcześniej przyjął on od papieża Innocentego IV (1243-1254) koronę królewską wraz z tytułem króla Rusi (1253). Do ceremonii doszło w Drohiczynie, innym pogranicznym mieście Rusi Halickiej, co prawdopodobnie wynikało z dążenia uniknięcia ewentualnych zatargów z prawosławną hierarchią i chanem Złotej Ordy ${ }^{12}$.

Dla św. Serapiona, bezpośredniego świadka inwazji tatarskiej oraz wnikliwego obserwatora pierwszych dekad niewoli ojczyzny, los mieszkańców Dracza i Przemyśla zdaje się stanowić ostrzeżenie przed wejściem na drogę zwątpienia w ortodoksję, ,małowiercy" bowiem okazują się być bardziej grzeszni niż poganie (w domyśle Tatarzy) ${ }^{13}$. Dla Pachymeresa tragedia dyrracheńczyków raczej nie prowokuje do jednoznacznych skojarzeń z brakiem cnót mieszkańców zburzonego i zalanego przez wody grodu, aczkolwiek zapewne znane mu były dawne spory patriarchów z Nikei z biskupami bizantyńskiego Zachodu ${ }^{14}$. Religijne zróżnicowanie mieszkańców Dyrrachion również mogło być mu znane. Kilkadziesiąt lat wcześniej metropolita Konstantyn Kabasilas (1224-1235) zwrócił się o radę do cenionego kościelnego kanonisty, wówczas arcybiskupa Bułgarii Demetriusza Chomatenosa (przed 1150-przed 1235). Pisał, że na obszarze metropolii dyrracheńskiej relacje jego podopiecznych z łacinnikami przybrały gorszące formy. Prawosławni biskupi wyświęcali łacińskich kapłanów, pogrzeby i inne ceremonie religijne łacinników zaś często odbywały się w świątyniach prawosławnych i odwrotnie, co nie spotykało się

12 Zdaniem D. Dąbrowskiego (Daniel Romanowicz król Rusi (ok. 1201-1264). Biografia polityczna, Kraków 2012, s. 267-406) akt koronacji nie spotkał się ze sprzeciwem prawosławnej hierarchii Rusi Halickiej. Pisze jednak dalej, że z pewnością nie był jednoznaczny z kościelną unią, ponadto w późniejszych latach Daniel został zmuszony do manifestacyjnych gestów posłuszeństwa wobec przedstawicieli chana (np. zburzenie umocnień najważniejszych grodów państwa Romanowiczów).

13 W. von Scheliha, Nicht-chronialische Schriftquellen der Rus' zur Geschichte der ,Slavia Asiatica” im 13. und 14. Jahrhundert, w: Geschichte der Slavia Asiatica. Quellenkundliche Probleme, red. Ch. Lübke - I. Milftakhova - W. von Scheliha, Leipzig 2013, s. 89-97, 108-110. Por. z obrazem ówczesnego Przemyśla jako „forum wielokulturowości”, miasta będącego siedzibą prawosławnego biskupa, którego podopieczni koegzystują z lokalną łacińską mniejszością. Zob. A.S. Fenczak, Wczesnośredniowieczny Przemyśl w świetle źródel historycznych, w: Przemyśl wczesnośredniowieczny, Origines Polonorum, t. 3, red. E. Sosnowska, Warszawa 2010, s. 73, 80-81.

14 A.M. T(albot), Pachymeres, George, w: ODB III, s. 1550; L. Neville, Guide to Byzantine historical writing, Cambridge 2016, s. 237-242. 
ze sprzeciwem wiernych. Metropolita zwrócił się o radę, jak ma postępować, do arcybiskupa, którego z racji autorytetu traktował jako swojego duchowego zwierzchnika i rozjemcę w sprawach spornych ${ }^{15}$. Uzyskał wówczas odpowiedź, że powinien zachować powściągliwość w takich okolicznościach. Niemniej zdaniem arcybiskupa małżeństwa mieszane są dopuszczalne tylko pod warunkiem zawarcia ich w obrządku prawosławnym, inaczej są nieprawne. Podobnie księża wyświęceni przez biskupów łacinników powinni zostać zawieszeni w sprawowaniu liturgii ${ }^{16} . \mathrm{Z}$ odpo-

15 G. Prinzing, A Quasi Patriarch in the State of Epiros: the Autocephalous Archbishop of „Boulgaria” (Ochrid) Demetrios Chomatenos, „Zbornik Radova Vizantološkog Instituta" 41 (2004) 165-182.

16 Odpowiedzi na, niestety niezachowane, pisma metropolity Kabasilasa mógł zredagować biskup Jan z Kitros. Zob. J. Darrouzès, Les résponses cannoniques de Jean de Kitros, REB 31 (1973) s. 326-327, 330-331; Demetrii Chomateni, Ponemata diaphora, ed. G. Prinzing, Berlin-New York 2002, s. 3*, 48-49*; 55-56*, 58*, 310*, 319*; A. Pavlov, Komu prinadležat' kanoničeskie otvety, avtorom kotorych'sčitalsja Joann, episkop kritstki (XIII veka)?, VV 1 (1894) s. 491-502. Sam arcybiskup (Demetrii Chomateni, Ponemata diaphora, s., 119*-120*, nr 46, s. 178-182, 198*-200*, nr 100, s. 326-330) wypowiadał się w konkretnych jednostkowych wypadkach bardziej pryncypialnie. Zob. D.M. Nicol, Refugees, Mixed Population and Local Patriotism in Epiros and Western Macedonia after the Fourth Crusade, w: XV Congrès International d'Études Byzantines, Rapports et co-raports, Athènes 1976, s. 3-33. Pamiętać należy, że do takich specyficznych kontaktów dochodziło w warunkach religijnej konfrontacji na zachodnich Bałkanach po 1204 roku. Aczkolwiek Innocenty III (1198-1216) potępił najazd krzyżowców, to jednak był przekonany, że nastał dogodny historyczny moment umożliwiający zjednoczenie obu Kościołów. Zasadniczym problemem było obranie skutecznej metody postępowania z prawosławną hierarchią i kapłanami. Dotychczasowe rozwiązania użyte w różnych częściach świata śródziemnomorskiego zakładały pełne podporządkowanie obu grup Rzymowi. W pierwszych dekadach po czwartej krucjacie w Kościele rzymskim narastało przekonanie że, papież powinien bezpośrednio decydować o nominacji biskupów na tych ziemiach. „Grecy” natomiast wraz ze swoimi kapłanami powinni być posłuszni i regularnie płacić dziesięciny. Nowy porządek udało się wprowadzić częściowo na ziemiach Peloponezu (Morei), Attyki, Beocji czy Tesalii, nierzadko posuwając się nawet do wypędzania prawosławnych biskupów. Zob. J. Longnon, The Frankish States in Greece, 1204-1311, w: A History of the Crusades. Vol. II, The Later Crusades, 1189-1311, ed. K.M. Setton and al., Madison - Milwauke - London 1969, s. 235-274, zwł. 250-253; E. Patlagean, Chrześcijaństwo greckie: rozpad cesarstwa i panowanie łacińskie (1204-1274), w: Historia chrześcijaństwa, t. 5: Ekspansja Kościoła rzymskiego 1054-1274, red. A. Vauchez, Warszawa 2001, s. 552-579; Z. Pentek, Cesarstwo Łacińskie 1204-1261. Kolonialne państwo krzyżowców czy Neobizancjum?, Poznań 2004, s. 212-219; J. Bonarek - T. Czekalski - S. Sprawski S. Turlej, Historia Grecji, Kraków 2005, s. 385-387; M. Balard, Eaciński Wschód. XI-XV wiek, tł. W. Ceran, Kraków 2010, s. 258-263; D. Jacoby, Po IV krucjacie - Cesarstwo 
wiedzi udzielonej metropolicie brakuje konkretnych danych co do lokalizacji takich praktyk. Mogły one mieć miejsce nie tylko w Dyrrachion, ale w nadmorskich miastach Alessio czy Awlona, gdzie od XI stulecia można dostrzec obecność różnych przybyszów z łacińskiego Zachodu (pielgrzymów, krzyżowców, najemników czy kupców). Również wewnątrz terytorium metropolii (np. w Arbanon) od wieków funkcjonowały społeczności poczuwające się do więzi z Kościołem łacińskim ${ }^{17}$. W duchu takiej koegzystencji wyznaniowej zapewne dorastał późniejszy biskup kalabryjskiego Krotonu (Cotrone) w Italii znany jako Mikołaj z Durazzo (zm. 1276). Pachymeres zapamiętał go jako „człowieka uczonego i rozprawiającego o teologii w dwóch językach". Mikołaj mimo początkowego patronatu Hohenstaufów osiągnął duże wpływy w rzymskiej kurii, przyjmowano go również i słuchano na dworach cesarskich w Nikei i Konstantynopolu. Stał się szczególnie zauważalną postacią w trakcie bezpośrednich negocjacji przygotowujących warunki unii obu Kościołów na drugim soborze zwołanym do Lyonu w 1274 roku. Jako teolog budził zainteresowanie Tomasza z Akwinu, który z jego pracy (Liber de processione spiritus sancti et fide trinitatis contra errores Graecorum, szerzej znanej jako Libellus) czerpał argumenty do teologicznych dysput z „Grekami”"18.

Lacińskie Konstantynopola oraz państwa frankijskie, w: Bizancjum 1024-1492, t. 2, tł. J. Kozłowska - R. Piotrowski, Warszawa 2015, s. 253-258, 260-261.

17 Biskupi Rzymu nigdy nie uznali decyzji cesarzy-ikonoklastów o wyjęciu spod ich jurysdykcji terytorium Illyricum. Kancelaria papieska w IX-XII wieku ustawicznie podkreślała zwierzchność Kościoła rzymskiego nad tym obszarem. Zob. Codex diplomaticus regni Croatiae, Dalmatiae et Sclavoniae, ed. T. Smičiklas, Zagreb 1907, t. 2, nr 2, 34, $35,51,74,82,91,105,112$.

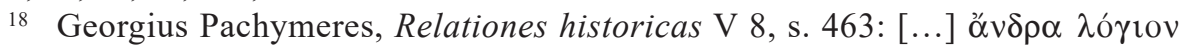

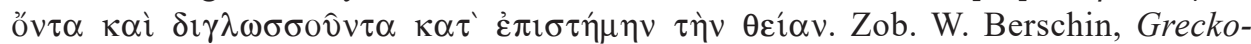
tacińskie średniowiecze. Od Hieronima do Mikołaja z Kuzy, tł. K. Liman, Gniezno 2003, s. 389-390; Patlagean, Chrześcijaństwo greckie, s. 578-579. Pachymeres z czasów, kiedy jeszcze pobierał podstawy swojego wykształcenia w Nikei przed odzyskaniem Konstantynopola z rąk łacinników, mógł jeszcze pamiętać o sporach między patriarchami rezydującymi tutaj „na wygnaniu” a biskupami będącymi stronnikami władcy zachodnich Bizantyńczyków - koronowanego w Tesalonice cesarza Teodora Komnena Dukasa (ok. 1223-1230). Manifestując prawo do instytucjonalnej autonomii, podkreślali swoje poparcie dla biskupich nominacji tego władcy. Dotyczyły one m.in. Dyrrachion, którego rangę kościelną i polityczną definiowali w kategoriach bastionu ortodoksji chroniącego Romanię przed zakusami łacinników. Zob. Epirotica saeculi XIII, ed. V. Vasilevskij, VV 3 (1896) nr 15, s. 265-267, nr 17, s. 276; Lettre de Georges Bardanes, metropolite de Corcyre, au Patriarche oequmenique Germain II, 1226-1227 c., red. R.J. Loenertz „Epeteris Hetaireias Byzantinon Spoudon” 33 (1964) 
Pachymeres do mieszanych wyznaniowo związków nie był usposobiony negatywnie, z uznaniem wyrażał się o ich potomstwie - ,gasmulach". W jego czasach potocznie tak nazywano synów zrodzonych przez romejskie kobiety pozostające $\mathrm{w}$ związkach $\mathrm{z}$ Wenecjanami. Z racji obecności dużej ich społeczności takie małżeństwa zapewne nie były rzadkością w Dyrrachion ${ }^{19}$. Opis destrukcji tutejszej wspólnoty brał się z innych powodów, zapewne niebagatelną rolę mogła tu odegrać określona forma krytyki cesarza Michała VIII Paleologa jako polityka i władcę odpowiedzialnego za Kościół. Pachymeres, pisząc kilkanaście lat po jego śmierci, Dzieje współczesne, eksponuje nieszczęścia, jakie dotknęły Romajów po odzyskaniu Konstantynopola. Radość ze zwycięstwa przyćmiły detronizacja i oślepienie jedenastoletniego cesarza Jana IV Laskarisa (1258-1261) pozostającego pod opieką Paleologa. Następstwem była ekskomunika Michała ogłoszona przez Arseniusza Autoreianosa (1260-1265), wyniszczający konflikt z cesarzem zakończony depozycją patriarchy i jego dożywotnim wygnaniem ${ }^{20}$. Wystąpienia licznych i popularnych wśród duchownych i świeckich ,arsenitów” odmawiających legitymizmu poczynaniom cesarza i późniejszych patriarchów zaczęły ciążyć Kościołowi. Do tych konfliktów dołączył w następnej dekadzie zryw sprzeciwu wobec zgody cesarza Michała VIII na unię z Kościołem rzymskim potwierdzoną po II soborze lyońskim. Ustalenia, podjęte na soborze w Lyonie, cesarz wdrażał bezwzględnie, sięgając po przemoc wobec opornych niezależnie od ich

nr 12, 13, s. 112, 113, s. 99, s. 117, s. 101-102; A.D. Karpozilos, The Ecclesiastical Controversy between the Kingdom of Nicea and the principality of Epiros (1217-1233), Thessalonike 1973, s. 79-81.

19 Georgius Pachymeres, Relationes historicas III 9, s. 253. Cechować ich miała „roztropność w dziełach wojskowych i ostrożność Romajów połączona z żarliwością i dumą Franków”. „Gasmulowie” służyli we flocie Michała VIII, przyczyniając się do krótkotrwałego odrodzenia morskiej potęgi Romanii. Zob. M. B(rand), Gasmoulos, w: ODB II, s. 823; D.M. Nicol, Byzantium and Venice. A study in diplomatic and cultural relations, Cambridge 1988, s. 199, 232-234; R. D'Amato, The Last Marines of Byzantium: Gasmouloi, Tzakones and Prosalentai. A Short History and a Proposed Reconstruction of their Uniforms and Equipment, ,Journal of Mediterranean Studies” 19/2 (2010) s. 221-223, 227-228, 238 (rys. nr 1). Również w cesarskiej rodzinie małżeństwa z księżniczkami z Europy łacińskiej nie były czymś odosobnionym. Zob. M. Dąbrowska, Łacinniczki nad Bosforem. Matżeństwa bizantyńsko-łacińskie w cesarskiej rodzinie Paleologów (XIII-XIV w.), Łódź 1996.

20 Georgius Pachymeres, Relationes historicas III 10, 14, 19, 23; IV 1, 2, 3, 4, 5, $6,7,8,9,10,11,12,13,14,15,16,17,18,19,20,21,22,23,24$, s. 255-259, 267-271, 281-283, 295-297, 330-397. 
społecznego statusu ${ }^{21}$. Unia miała $\mathrm{w}$ zamyśle uchronić Bizancjum przed inwazją łacinników przygotowywaną przez potężnego wówczas Karola I Andegawena, który po 1268 roku energicznie zaczął budować przyczółki swoich wpływów na zachodnich peryferiach państwa bizantyńskiego.

Opis materialnego i moralnego upadku miasta wpisuje się w mroczny nurt narracji lat 1274-1282, tym zapewnie można tłumaczyć chronologię Pachymeresa, w której do trzęsienia ziemi dochodzi w marcu 1273 roku. Czy w takich okolicznościach można interpretować zapis historyka jako karę Bożą za postępowanie cesarza wobec wiernych ortodoksji? Niekoniecznie jednak należy przedkładać tak uproszczone wyjaśnienie. Autor Dziejów współczesnych zaliczał się do ścisłej elity umysłów czasów „renesansu Paleologów”. Urodzony i wychowany w Nicei stanął u boku Michała VIII Paleologa w wielkim dziele przywracania świetności cesarskiego Miasta, podupadłego duchowo i materialnie pod rządami łacinników. W odzyskanej stolicy kierował odradzającymi się szkołami i instytucjami, w których miały się kształcić nowe pokolenia elity odrodzonej Romanii ${ }^{22}$. Nieobce mu były poglądy teologów, historiografów uzmysławiających sobie rozbieżność między doskonałością Stwórcy a niedoskonałością świata fizycznego uzewnętrznioną w postaci wszelkich klęsk żywiołowych, katastrof (trzęsień ziemi, powodzi) i przerażających fenomenów przyrodniczych (epidemie). Godził to, jak wiemy, z wiedzą przyrodniczą, w świetle której bezpośrednim powodem trzęsień ziemi są podziemne ruchy. W ten sposób, Pachymeres oraz jego następcy mogli interpretować kolejne kataklizmy jako odzwierciedlenie plag spadających na Romanię, analogicznie jak najazdy Turków, Serbów, grabieże Katalończyków czy wojny domowe bądź spory religijne - odbierając wszystkie powyższe wydarzenia jako zapowiedź zbliżającego się kresu dziejów ${ }^{23}$.

21 Georgius Pachymeres, Relationes historicas V 15, 16, 17, 18, 19, 20, 21, 22, 23 , 24, 25, 26, 27, 28, 29; VI 10, 11, 12, 15, 16, 30, 31, s. 487-535, 569-581, 637-639.

22 A.M. T(albot), Pachymeres, George, w: ODB III, s. 1550; L. Neville, Guide to Byzantine historical writing, Cambridge 2016, s. 237-242.

23 Georgius Pachymeres, Relationes historicas IX 15, s. 259. Stąd trzęsienia ziemi i towarzyszące im zjawiska przykuwały nie tylko uwagę takich znanych historyków, jak Pachymeres czy w późniejszym okresie jego uczeń i kontynuator Nikefor Gregoras, odnotowali je w wypadku Konstantynopola (1343) czy wyspy Chios (1389) również twórcy kronik: P. Schreiner, Die byzantinischen Kleinchroniken, t. 1, nr 8, 87, 107, 113, Wien 1975, s. 83, 612, 670, 680; P. Schreiner, Die byzantinischen Kleinchroniken, t. 2, Wien 1977, s. 258, 337-338; P. Schreiner, Die byzantinischen Kleinchroniken, t. 3, Wien 1979, s. 126. W niektórych okolicznościach (Kallipolis 1354) trzęsienia ziemi miały umożliwiać inwazje barbarzyńców (Turków) na ziemie stanowiące trzon ówczesnego Cesarstwa. 
Michał VIII Paleolog został również przedstawiony w Dziejach wspótczesnych jako władca zasłużony dla państwa oraz odnowiciel jego potęgi. Potrafił odeprzeć wrogów zewnętrznych, uniknął wojen domowych. Kiedy Pachymeres tworzył swoje dzieło, jego czytelnicy, dostrzegając pogarszające się położenie państwa bizantyńskiego pod rządami Andronika II Paleologa (1282-1320), byli świadomi tego kontrastu. Takie wydarzenia, jak katastrofa, która dotknęła Dyrrachion, ucieczka metropolity Niketasa stały się dla historyka elementami dysonansu w ocenie wydarzeń tamtych lat. Postępki cesarza Michała VIII Paleologa, mimo jego niewątpliwych zasług, sprowadzają na manowce wiernych mu kapłanów, którzy zawodzą swoich podopiecznych w trudnych momentach dotykających niedoskonały świat doczesny.

Podsumowaniem tej historii jest późniejsza kościelna kariera Niketasa, który nie znika z kart historii mimo porzucenia swoich wiernych. Ponad dwadzieścia lat później, nadal pozostając metropolitą Dyrrachion, będzie uczestniczyć w stołecznym synodzie u boku cesarza Andronika II Paleologa ${ }^{24}$. Uwzględniając fakt, że został metropolitą przed 1270 rokiem, był najdłużej urzędującym biskupem Dyrrachion w wiekach średnich. Nie przeszkodziły mu w tym nawet zniszczenie miasta w trzęsieniu ziemi czy kolejne inwazje łacinników. Niezależnie od krytyki Pachymeresa Niketas zaliczał się, podobnie jak jego poprzednicy Konstantyn Kabasilas, Roman, Chalkutzes, do lojalnych popleczników Paleologów. Źródła niestety milczą, jak przetrwał na swoim urzędzie w czasach unii oraz jak uniknął depozycji po objęciu władzy przez Andronika II, kiedy to nowy cesarz przeprowadził czystkę wśród biskupów przychylnych unii ${ }^{25}$. Niewykluczone, że zawdzięczał to oportunizmowi, przystosowując się do kolejnych zmian polityki kościelnej pierwszych Paleologów. Pamiętać jednak należy, że

Nawet pomniejsze trzęsienia, jeśli pociągały za sobą ofiary w ludziach, to z racji czynionych przez nie spektakularnych szkód (np. runięcie kopuły stołecznego kościoła Mądrości Bożej w 1346 roku) traktowano je jako symboliczny znak nadchodzących czasów. Zob. P. Janiszewski, Klęski jako demoniczna cecha przydana przez Boga elementom świata fizycznego, „Etyka” 30 (1997) s. 51-63; B. C(roke), Earthquakes, w: ODB I, s. 669; H.-M. Congourdeau, Les Byzantines face aux catastrophes naturelles sous les Paléologues, REB 67 (2009) s. 151-163.

24 V. Laurent, Les regestes des actes du patriarchat de Constantinople, vol. Les actes des patriarches, fasc. IV. Les regestes de 1208 a 1309, Paris 1971, nr 1569; G. Fedalto, Hierarchia Ecclesiastica Orientalis, t. 1, Firenze 1988, s. 529.

25 Georgius Pachymeres, Relationes historicas IX 23, ed. A. Failler, Paris 1999, s. 275. Zob. Prosopographische Lexikon der Palaiologenzeit, t. 1, z. 8, nr 20276, ed. E. Trapp, Wien 1986. 
Niketas był biskupem ważnego dla Bizancjum miasta, lojalność miejscowych wyznawców prawosławia nie była kwestią wyłącznie religijną. Potwierdza to również szczodrość Michała VIII i jego kolejnych następców wobec instytucji kościelnych na obszarze metropolii dyrracheńskiej manifestowana praktycznie aż do końca panowania bizantyńskiego w tej części Bałkanów ${ }^{26}$. Rozkwit tutejszych kościołów czy klasztorów można potraktować jako jeden z objawów renesansu kultury bizantyńskiej, jaki objął nie tylko odzyskaną stolicę, ale również prowincje. W wypadku metropolii położonej na odległej zachodniej granicy była świadectwem cesarskiego patronatu, którego nie kwestionowali już prawosławni hierarchowie z zachodnich Bałkanów.

\section{The Metropolitan Bishops of Dyrrachion in the Face of Natural Disasters and the Byzantine State Crisis ( $13^{\text {th }}$ Century)}

(summary)

In the $13^{\text {th }}$ century, the bishops of Dyrrachion faced numerous religious and political problems. They also had to confront the natural disaster (earthquake and tsunami) that hit the city in 1271, subsequently abandoned by the bishop Niketas and conquered by the Latins. The historian Georgios Pachymeres described the course of the cataclysm and its aftermath, taking into account the criticism of the Church policy of Emperor Michael VIII Paleologos. In turn, for St. Serapion from distant Rus, the fate of the inhabitants of Dyrrachion, like the fate of the border town of Przemyśl, was a consequence of a moral decline caused by close contacts with Latins from Poland. Despite the opinion about the influence of Catholics in Dyrrachion, the support of the emperor from Constantinople ensured the protection of the Orthodox church organization in this part of the western Balkans.

Keywords: Byzantium; Rus; Dürres; Dyrrachion; Albania; bishop; conflict; Catholic Church; Orthodox Church; earthquake; Georgius Pachymeres; St. Serapion

\section{Metropolici Dyrrachion wobec naturalnych katastrof i kryzysu Bizancjum w XIII wieku}

(streszczenie)

W XIII wieku biskupi Dyrrachion (Dyrrachion) stanęli wobec wielu problemów religijnych i politycznych. Musieli również stawić czoło spowodowanej siłami natury katastrofy (trzęsienie ziemi i tsunami), jaka dotknęła miasto w 1271 roku, potem porzucone

26 Buschhausen, Die Marienkirchen von Apollonia in Albanien, s. 161-182. 
przez biskupa Niketasa (Niketas) i zdobyte przez łacinników. Historyk Jerzy Pachymeres (Georgios Pachymeres) opisał przebieg kataklizmu i jego następstwa, uwzględniając krytykę polityki kościelnej cesarza Michała VIII Paleologa (Michael VIII Paleologos). Z kolei dla św. Serapiona (Serapion) z dalekiej Rusi los mieszkańców Dyrrachion, podobnie jak pogranicznego Przemyśla, był konsekwencją moralnego upadku wywołanego bliskimi kontaktami z łacinnikami. Mimo opinii o wpływie katolików w Dyrrachion poparcie cesarza z Konstantynopola zapewniało ochronę prawosławnej organizacji kościelnej w tej części zachodnich Bałkanów.

Słowa kluczowe: Bizancjum; Ruś; Dürres; Dyrrachion; Albania; biskup; trzęsienie ziemi; tsunami; konflikt; Kościół katolicki; Kościół prawosławny; Georgius Pachymeres; św. Serapion

\section{Bibliografia}

\section{Źródła}

Codex diplomaticus regni Croatiae, Dalmatiae et Sclavoniae, ed. T. Smičiklas, Zagreb 1907. Demetrius Chomatenus, Ponemata diaphora, ed. G. Prinzing, Berlin - New York 2002. Epirotica saeculi XIII, ed. V. Vasilevskij, „Vizantijskij Vremennik” 3 (1896) 233-299.

Georgius Pachymeres, Relationes historicas, t. 2-3, ed. A. Failler - V. Laurent, Paris 1984-1999.

Latopis nowogrodzki pierwszy starszej redakcji. Unikatowy zabytek piśmiennictwa staroruskiego i jego polski przekład, red. i tł. Z.A. Brzozowska - I.N. Petrov, Łódź 2019.

Les listes de préséance byzantines des $I X^{e}$ et $X^{e}$ siècles, introduction, texte, traduction et commentaire par N. Oikonomidès, Paris 1972.

Lettre de Georges Bardanes, metropolite de Corcyre, au Patriarche oequmenique Germain II, 1226-1227 c., ed. R.J. Loenertz „Epeteris Hetaireias Byzantinon Spoudon” 33 (1964) 87-118.

Notitiae episcopatuum Ecclesiae Constantinopolitane, texte critique, introduction et notes J. Darrouzès, Paris 1981.

Schreiner P., Die byzantinischen Kleinchroniken, t. 1-3. Wien 1975-1979.

Slovo blažennogo Serapiona o malover'je, w: „Slova” Serapiona Vladimirskogo, ed. i tł. V.V. Kolesov, Pamjatniki Literatury Drevnej Rusi: XIII vek, Moskva 1981, s. 452-455.

Tăpkova-Zaimova V. - Miltenova A., Istoriko-apokalptičnata knižnina văv Vizantija i srednovekovna Bălgarija, Sofija 1996.

\section{Opracowania}

D'Amato R., The Last Marines of Byzantium: Gasmouloi, Tzakones and Prosalentai. A Short History and a Proposed Reconstruction of their Uniforms and Equipment, „Journal of Mediterranean Studies” 19/2 (2010) s. 219-248. 
Berschin W., Grecko-łacińskie średniowiecze. Od Hieronima do Mikołaja z Kuzy, tł. K. Liman, Gniezno 2003.

Bonarek J., Sytuacja Cesarstwa Bizantyńskiego w przededniu IV krucjaty, w: IV Krucjata. Historia. Reperkusje. Konsekwencje, red. Z.J. Kijas - M. Salamon, Kraków 2005, s. 31-53.

Bonarek J. - Czekalski T. - Sprawski S. - Turlej S., Historia Grecji, Kraków 2005.

Brzozowska Z.A., Opowieść o zdobyciu Konstantynopola przez uczestników czwartej wyprawy krzyżowej (6712/1204) w średniowiecznej ruskiej tradycji historiograficznej, „Slavia Antiqua” 67 (2016) s. 109-151.

Buschhausen H., Die Marienkirchen von Apollonia in Albanien. Byzantiner, Normannen und Serben im Kampf um die Via Egnatia, Wien 1976.

Congourdeau H.M., Les Byzantines face aux catastrophes naturelles sous les Paléologues, „Revue des études byzantines” 67 (2009) s. 151-163.

Darrouès J., Les résponses cannoniques de Jean de Kitros, „Revue des études byzantines" 31 (1973) s. 319-334.

Dąbrowska M., Łacinniczki nad Bosforem. Matżeństwa bizantyńsko-łacińskie w cesarskiej rodzinie Paleologów (XIII-XIV w.), Łódź 1996.

Dölger F., Regesten der Kaiserurkunden des oströmischen Reiches von 565-1453, T. 1. Regesten von 565-1025, München - Berlin 1924.

Ducéllier A., La façade maritime de l'Albanie au Moyen Age. Durazzo et Valona du XI au XVe siècle, Thessaloniki 1981.

Dudek J., „Cała ziemia dyrracheńska” pod panowaniem bizantyńskim $w$ latach 1005-1205, Zielona Góra 1999.

Dudek J., Metropolici Dyrrachion od VII do XIII wieku. Próba charakterystyki, „Balcanica Posnaniensia. Acta et studia" 18 (2011) s. 62-87.

Dudek J., Biskupi Dyrrachion w strukturach patriarchatu Konstantynopola (VII-X w.), „Vox Patrum” 58 (2013) s. 221-236.

Encyclopedia of the Early Church, t. 1, red. A. Di Bernardino, tt. A. Walford, Cambridge 1992.

Failler A., Chronologie et composition dans l'Histoire de Georges Pachymère, (cz. II) „Revue des études byzantines” 39 (1981) s. 145-249.

Fedalto G., Problemi di cronotassi e di giurisdizione nei vescovadi del Ducato di Durazzo fino alla dominazione occidentale, w: Studi Albanologici, Balcani, Bizantini e Orientali in onore di Giuseppe Valentini, red. L.S. Olschke, Firenze 1986, s. 51-64. Fedalto G., Hierarchia Ecclesiastica Orientalis, t. 1, Firenze 1988.

Fenczak A.S., Wczesnośredniowieczny Przemyśl w świetle źródet historycznych, w: Przemyśl wczesnośredniowieczny, Origines Polonorum, t. 3, red. E. Sosnowska, Warszawa 2010, s. 39-91.

Forstner D., Świat symboliki chrześcijańskiej, tł. W. Zakrzewska - P. Pachciarek R. Turzyński, Warszawa 1990.

Grumel V., Les regestes des actes du patriarchat de Constantinople, t. 1: Les actes des patriarches, z. 3: Les regestes de 1043 a 1206, Paris 1947. 
Grumel V., L'annexion de l'Illyricum Oriental, de la Sicile et de la Kalabrie au Patriarchat de Constantinople, ,Reserches des science religieuse” 40 (1952) s. 191-200.

Guidoboni E. - Comastri A., Catalogue of earthquakes and tsunamis in the Mediterranean area from the $11^{\text {th }}$ to the $15^{\text {th }}$ Century, Rome 2005.

Hauziński J. - Leśny J., Historia Albanii, Wrocław 1993.

Jacoby D., Po IV krucjacie - Cesarstwo Eacińskie Konstantynopola oraz państwa frankijskie, w: Bizancjum 1024-1492, t. 2, tł. J. Kozłowska-R. Piotrowski, Warszawa 2015, s. 244-261.

Janin J., Dyrrachium, DHGE XIV 1248-1252.

Janiszewski P., Klęski jako demoniczna cecha przydana przez Boga elementom świata fizycznego, ,Etyka” 30 (1997) s. 51-63.

Karpozilos A.D., The Ecclesiastical Controversy between the Kingdom of Nicea and the principality of Epiros (1217-1233), Thessalonike 1973.

Kislinger E., Dyrrhachion und die Küsten von Epirus und Dalmatien im frühen Mittelalter - Beobachtungen zur Entwicklung der byzantinischen Oberhoheit, „Millenium" 8 (2011) s. 313-352.

Laurent V., Les regestes des actes du patriarchat de Constantinople, t. 1: Les actes des patriarches, z. 4: Les regestes de 1208 a 1309, Paris 1971.

Longnon J., The Frankish States in Greece, 1204-1311, w: A History of the Crusades. Vol. II, The Later Crusades, 1189-1311, ed. K.M. Setton et al., Madison - Milwauke - London 1969, s. 235-274.

Miraj L.F., Dyrrachion in the Early Christian and Byzantine Period, Tiranë 2013.

Morrisson C., Despotat Epiru i Cesarstwo Tesaloniki, w: Świat Bizancjum, t. 3: Bizancjum i jego sasiedzi 1204-1453, red. A. Laiou - C. Morrisson, tł. A. Graboń, Kraków 2013, s. 343-355.

Nallbani E., Transformations et continuité dans l'ouest des Balkans: le cas de la civilisation de Komani (VI-IX siècles), w: L'Illyrie méridionale et l'Epire dans l'Antiquité. IV. Actes du IV colloque internationale de Grenoble, 10-12 octobre 2002, ed. P. Cabannes - J.-L. Lamboley, Paris 2004, s. 481-490.

Neville L., Guide to Byzantine historical writing, Cambridge 2016.

Nicol D.M., Refugees, Mixed Population and Local Patriotism in Epiros and Western Macedonia after the Fourth Crusade, w: XV Congrès International d'Études Byzantines, Rapports et co-raports, Athènes 1976, s. 3-33.

Nicol D.M., The Despotate of Epiros 1267-1479. A contribution to the history of Greece in the middle ages, Cambridge 1984.

Nicol D.M., Byzantium and Venice. A study in diplomatic and cultural relations, Cambridge 1988 .

Patlagean E., Chrześcijaństwo greckie: rozpad cesarstwa $i$ panowanie tacińskie (1204-1274), w: Historia chrześcijaństwa, t. 5: Ekspansja Kościoła rzymskiego 1054-1274, red. A. Vauchez, Warszawa 2001, s. 552-579. 
Parisse M. - Martin J.-M., Ekspansja Kościoła rzymskiego. Południowe Włochy i Sycylia, w: Historia chrześcijaństwa, t. 5: Ekspansja Kościoła rzymskiego 1054-1274, red. A. Vauchez, Warszawa 2001, s. 249-254.

Pavlov A., Komu prinadležat' kanoničeskie otvety, avtorom kotorych'sčitalsja Joann, episkop kritstki (XIII veka)?, „Vizantijskij Vremennik” 1 (1894) s. 491-502.

Pentek Z., Cesarstwo Łacińskie 1204-1261. Kolonialne państwo krzyżowców czy Neobizancjum?, Poznań 2004.

Podskalsky G., Chrześcijaństwo i literatura liturgiczna na Rusi Kijowskiej (988-1237), tł. J. Zychowicz, Kraków 2000.

Prinzing G., A Quasi Patriarch in the State of Epiros: the Autocephalous Archbishop of ,Boulgaria” (Ochrid) Demetrios Chomatenos, „Zbornik Radova Vizantološkog Instituta" 41 (2004) s. 165-182.

Prosopographische Lexikon der Palaiologenzeit, ed. E. Trapp, Wien 1976-1996.

Santoro S., Lo stato degli studi sull'urbanistica di Epidamnos-Dyrrachium, w: Progetto Durrës. L'idagine sui beni culturali albanesi dell' antichità e del Medioevo. Tradizioni di studio a confronto, red. M. Buora - S. Santoro, Trieste 2003, s. 149-208.

Saradi H., Aspects of early Byzantine urbanism in Albania, w: The Medieval Albanians, Athens 1998, s. 81-124.

Scheliha von W., Nicht-chronialische Schriftquellen der Rus'zur Geschichte der „Slavia Asiatica” im 13. und 14. Jahrhundert, w: Geschichte der Slavia Asiatica. Quellenkundliche Probleme, red. Ch. Lübke - I. Milftakhova - W. von Scheliha, Leipzig 2013, s. 88-147.

Słownik starożytności słowiańskich, t. 8, cz. 1: Suplementy i indeksy, Wrocław - Warszawa 1991.

The Oxford Dictionary of Byzantium, t. 1-3, ed. A. Kazhdan et al., New York - Oxford 1991.

Turlej S.T., Konflikt ikonoklastyczny a problem jurysdykcji nad Illyricum, „ZNUJ Studia Religiologica" 29 (1996) s. 33-77. 